Niepełnosprawność. Dyskursy pedagogiki specjalnej

Nr 27/2017

Disability. Discourses of special education

No. $27 / 2017$

\author{
Bartosz Atroszko, Paweł Atroszko
}

Uniwersytet Gdański

\title{
Porównanie studentów pedagogiki i pedagogiki specjalnej pod względem wybranych cech osobowości
}

Celem artykułu jest odpowiedź na pytanie: czy studenci pedagogiki i pedagogiki specjalnej różnią się pod względem cech osobowości ważnych z punktu widzenia wykonywania przyszłego zawodu? Ze względu na specyfikę zawodu pedagoga specjalnego oczekiwano, że studenci pedagogiki specjalnej będą różnili się od studentów pedagogiki cechami osobowości związanymi z większą odpornością psychiczną, zwłaszcza większą stabilnością emocjonalną, sumiennością, otwartością na doświadczenia, ekstrawersją oraz większą wrażliwością na potrzeby innych (wyższym poziomem ugodowości oraz niższą cyniczną wrogością). W badaniu wzięło udział 355 osób, w tym 184 studentów pedagogiki i 171 studentów pedagogiki specjalnej. Cechy tzw. Wielkiej Piątki (czyli ogólnego modelu struktury osobowości obejmującego pięć najważniejszych cech) były mierzone za pomocą polskiej wersji kwestionariusza Ten Item Personality Inventory (TIPI). Natomiast cyniczna wrogość była mierzona za pomocą polskiej wersji kwestionariusza Cook-Medley Hostility Inventory - Brief (CMHI Brief). W celu zbadania związku pomiędzy kierunkiem studiów a wybranymi cechami osobowości (Wielkiej Piątki oraz cynicznej wrogości) przeprowadzono analizę regresji logistycznej. Wyniki badania nie wykazały związku między kierunkiem studiów a badanymi cechami osobowości, co oznacza, że nie ma żadnych statystycznie istotnych różnic pomiędzy studentami pedagogiki i pedagogiki specjalnej w zakresie badanych cech osobowości.

Słowa kluczowe: studenci pedagogiki, studenci pedagogiki specjalnej, cechy osobowości, Wielka Piątka, cyniczna wrogość

\section{Comparing pedagogy and special education students' personality characteristics}

This article is an attempt to answer a question whether special education students differ from pedagogy students in terms of personality traits crucial from the point of view of future career. We assume that special education teachers are more exposed to stress in their professional work than other teachers. Therefore the profession of special education teacher requires specific individual resources to cope with stress. Because of that the special education students were expected to show personality traits associated with greater mental resilience. We assume that emotional stability, conscientiousness, extraversion, openness to experience and greater sensitivity to the needs of others (high agreeableness and low cynical hostility) are personality traits associated with higher level of mental resilience. A logistic regression analysis was performed to analyze the relationship between the field of study and the selected characteristics 
of personality. Total of 355 students participated in the study: 184 pedagogy students and 171 special education students. The traits of the Five-Factor Model of Personality were measured using the Polish version of the Ten Item Personality Inventory (TIPI) questionnaire. Cynical hostility was measured using the Polish version of the Cook-Medley Hostility Inventory - Brief (CMHI Brief) questionnaire. The results of the study showed no differences between education and special education students in terms of the selected personality traits crucial from the point of view of future career.

Keywords: pedagogy students, special education students, personality traits, Big Five, cynical hostility

\section{Wprowadzenie}

Bycie nauczycielem wymaga nie tylko pewnych formalnych kwalifikacji, ale również (a może przede wszystkim) zdolności interpersonalnych i odpowiednich cech osobowości. Samo przygotowanie merytoryczne to za mało, aby efektywnie wpływać na rozwój młodych ludzi. W szczególności dotyczy to pedagogów specjalnych, a więc nauczycieli pracujących z dziećmi niepełnosprawnymi. Praca nauczycieli jest bardzo stresująca, a wypalenie zawodowe $w$ tym zawodzie jest konsekwencją odczuwania chronicznego stresu [Kokkinos 2007, s. 229-243].

Przyjmuje się, że do pełnienia roli nauczyciela predestynują takie cechy, jak: opanowanie, cierpliwość, zrównoważenie emocjonalne i umiar w reakcjach [Kawka 1998, s. 85]. Na podstawie przeprowadzonych badań stwierdzono, że najczęściej oczekiwanymi cechami nauczyciela są: wyrozumiałość, miły sposób bycia, wykształcenie, duża wiedza, sprawiedliwość, opanowanie, uczciwość oraz wesołe, sympatyczne usposobienie [Kordziński 2013, s. 99]. W większości są to typowe kompetencje społeczne. Uczniowie podkreślają, że takie cechy nauczycieli, jak: życzliwość, uczciwość i umiejętność nawiązywania kontaktów, mają zdecydowany wpływ na ich poczucie bezpieczeństwa i stanowią podstawę budowania kontaktów zarówno z nauczycielami, jak i z innymi członkami społeczności klasowej i szkolnej [Kordziński 2013, s. 99].

Poza tym nauczyciele muszą posiadać pewne kompetencje diagnostyczne, które umożliwiają poznawanie uczniów, ich predyspozycji rozwojowych, zdolności, zainteresowań, ale i ograniczeń [Wosik-Kawali, Zubrzycka-Maciąg 2011, s. 7-9]. Diagnozowanie jest niezastąpione i konieczne w wychowaniu dzieci i młodzieży. W związku z tym zdolność dokonywania diagnozy może być postrzegane jako jedna z kompetencji nauczyciela [Rudek 2002, s. 125]. Jest to tak ważne, ponieważ spora część dzieci boryka się z różnego typu problemami i trudnościami. Około $20 \%$ dzieci i młodzieży w wieku szkolnym stanowią osoby z trudnościami wywierającymi wpływ na możliwości uczenia się oraz adaptacji społecznej, a więc tzw. uczniowie ze specjalnymi potrzebami edukacyjnymi [Strzyżewska 
2002, s. 53]. Wydaje się, że ta grupa uczniów wymaga szczególnych umiejętności i zasobów osobistych ze strony nauczyciela. Oprócz tego, specyfika zawodu nauczyciela wymusza od osób wykonujących ten zawód również ciągłego dokształcania się [Day 2004, s. 17].

Należy podkreślić, że rola nauczyciela zmienia się. Współczesny nauczyciel nie jest już osobą obarczoną przede wszystkim koniecznością przekazywania wiedzy [Strzyżewska, s. 54], chociażby ze względu na upowszechnienie Internetu i dostępu do wiedzy i informacji na niespotykaną wcześniej skalę. Coraz trudniej jest sprecyzować, jakiego typu umiejętności oraz wiedza upoważniają człowieka do wychowywania i nauczania [Strzyżewska, s. 54].

Każdy nauczyciel spełnia co najmniej dwie funkcje: wychowuje oraz naucza młodych ludzi. O ile dla procesu nauczania można wyróżnić pewien zasób wiedzy z zakresu dydaktyki i psychologii, który musi znać osoba pragnąca zawodowo uczyć innych, a także minimalny zakres umiejętności potrzebnych w tym względzie (umiejętność przemawiania do grupy osób etc.), o tyle w przypadku wychowania sprawa jest znacznie bardziej skomplikowana. Wychowanie można rozumieć jako wspomaganie indywidualnego rozwoju dziecka [Strzyżewska, s. 54]. Dla procesu wychowania cenniejsze od przekazywanej wiedzy są przede wszystkim dobre kontakty interpersonalne, wzajemna akceptacja i życzliwość, a także atmosfera zapewniająca poczucie bezpieczeństwa [Strzyżewska, s. 54]. Aby wychowywać dzieci i młodzież potrzebne są przede wszystkim pewne miękkie umiejętności oraz inteligencja emocjonalna. Dotyczy to zwłaszcza nauczycieli dzieci i młodzieży niepełnosprawnej. Praca nauczyciela z dzieckiem niepełnosprawnym nie może być ograniczona do samego procesu nauczania (rozumianego jako przekazywanie wiedzy), z pominięciem wychowania, wspierania ucznia, rozpoznawania jego problemów i budowania z nim relacji [Krause 2009, s. 21].

\section{Czy można nauczyć się bycia dobrym nauczycielem?}

Nasuwa się pytanie, na ile kompetencji potrzebnych do wychowywania dzieci i młodzieży (a więc również bycia dobrym nauczycielem) można się nauczyć na studiach, a na ile są one wykształcone we wcześniejszych okresach życia jako efekt interakcji wrodzonych predyspozycji, wychowania i doświadczeń życiowych. Z jednej strony podstawowe cechy osobowości, takie jak: ekstrawersja, ugodowość czy stabilność emocjonalna, kształtują się we wczesnych okresach życia i w okresie dorosłości w dużej mierze pozostają niezmienione. $Z$ drugiej strony kompetencje interpersonalne oraz inteligencję emocjonalną można z powodzeniem rozwijaći to niemal w każdym wieku. Wyniki badań wskazują na to, że inte- 
ligencja emocjonalna wykazuje wręcz tendencję do wzrostu wraz z wiekiem, a więc dorosłe osoby w toku swojego życia rozwijają tę umiejętność [Van Rooya i in. 2005, s. 689-700]. Fariselli, Ghini i Freedman doprecyzowują, że tylko niektóre elementy składowe inteligencji emocjonalnej i to $\mathrm{w}$ niewielkim stopniu rosną wraz z wiekiem [Fariselli i in. 2006, s. 2, data dostępu: 21.10.2017]. Kwestią otwartą pozostaje pytanie, $\mathrm{w}$ jakim stopniu studia pedagogiczne $\mathrm{w}$ swoim programie uwzględniają rozwój tego typu miękkich umiejętności i na ile studenci pedagogiki faktycznie je rozwijają.

Brakuje badań empirycznych dotyczących kształcenia pedagogów specjalnych [Brownell i in. 2005, s. 242-252]. Dobór odpowiednich kandydatów do zawodu pedagoga specjalnego jest sprawą kluczową [Parys, Olszewski 2009, s. 106]. Tym bardziej powinno nas niepokoić to, że - jak wskazują Parys i Olszewski obecnie w Polsce mamy do czynienia z negatywną selekcją na studia pedagogiczne, mniejszą liczbą kandydatów oraz minimalizowaniem wymagań stawianym kandydatom na studia [Parys, Olszewski 2009, s. 107]. Konsekwencją tego jest to, że "mamy źle przygotowanych nauczycieli, a część z nich nie powinna w ogóle być dopuszczona do pracy z dziećmi" [Krause 2009, s. 20].

$\mathrm{Z}$ wyników badania przeprowadzonego przez biuro karier Uniwersytetu Pedagogicznego w Krakowie wiadomo, że tylko 47\% absolwentów pedagogiki specjalnej (osoby, które obroniły pracę dyplomową w 2013 r.) wykonuje pracę związaną z ukończonym kierunkiem studiów. Na pytanie: Czy z perspektywy czasu wybratbyś ten sam kierunek studiów?, odpowiedzi twierdzącej "tak" udzieliło 58\% badanych, $26 \%$ odpowiedziało przecząco "nie", zaś $16 \%$ zaznaczyło opcję "Nie wiem". Główne przyczyny, dla których osoby zaprzeczyły, że wybrałyby ponownie ten sam kierunek studiów, to: oferta rynku pracy dla absolwentów tego kierunku jest mało atrakcyjna (56\%), program ksztatcenia nie spetnit moich oczekiwań (24\%), kierunek studiów wybratem dlatego, że nie dostałem się na pożądany przeze mnie kierunek (9\%), kierunek studiów wybrałem przypadkowo (4\%) [https://bks.up.krakow.pl/ htmlarea/ uploaded/pedagogika_specjalna_2013.pdf, dostęp: 21.10.2017].

\section{Model Wielkiej Piątki}

Osobowość definiuje się jako charakterystyczne dla danej osoby właściwości myślenia, odczuwania i działania [Myers 2003, s. 512]. Natomiast cecha osobowości jest to charakterystyczny wzorzec zachowań jednostki lub jej dyspozycja do odczuwania oraz działania w określony sposób [Myers 2003, s. 523]. Wielka Piątka stanowi obecnie najlepsze przybliżenie wymiarów podstawowych cech osobowości [Myers, s. 525]. Pojawienie się tego modelu jest jednym z najważniejszych 
wydarzeń w psychologii osobowości mających miejsce w ostatnich latach. Jest to ogólny model struktury osobowości i stanowi on podstawę koncepcyjną wielu współcześnie realizowanych prac z zakresu pomiaru osobowości [Hall i in. 2004, s. 346]. Na pięcioczynnikowy model osobowości nazywany Wielką Piątką (ang. Big five) składają się następujące cechy osobowości: ekstrawersja, ugodowość, sumienność, stabilność emocjonalna i otwartość na doświadczenia [Myers 2003, s. 526; Hall i in. 2004, s. 347]. Zgodnie z tym modelem cechy te są kluczowe i stanowią najbardziej ogólne wymiary pozwalające na wszechstronną charakterystykę osobowości.

W ramach badań empirycznych prowadzonych na całym świecie wykazano istnienie związku pomiędzy cechami Wielkiej Piątki a pewnymi aspektami (zarówno pozytywnymi, jak i negatywnymi) związanymi z wykonywaniem zawodu nauczyciela. Wykazano istnienie pozytywnego związku pomiędzy poziomem neurotyzmu (rozumianego jako odwrotność stabilności emocjonalnej) nauczyciela a problemami wychowawczymi jego uczniów [Ngidi, Sibaya, 2002], a także pomiędzy cechami Wielkiej Piątki a wypaleniem zawodowym nauczycieli [Kokkinos 2007, s. 229-243.]. Neurotyzm okazał się być predyktorem wszystkich wymiarów wypalenia zawodowego [Kokkinos 2007, s. 229-243]. Z drugiej strony wykazano związek pomiędzy otwartością na doświadczenia a poziomem zaangażowania $\mathrm{w}$ doświadczenia związane z kreatywnością oraz ze stylami nauczania wspierającymi kreatywność u nauczycieli przedszkolnych [Lee, Kemple 2014]. Wykazano istnienie negatywnego związku pomiędzy ekstrawersją i odczuwanym stresem, a także pozytywnego związku pomiędzy neurotyzmem a odczuwanym stresem $w$ grupie nauczycieli. $Z$ wyników badań wiadomo, że ekstrawersja i neurotyzm były najlepszymi predyktorami stresu [Fontana, Abouserie, 1993, s. 261-270] oraz, że introwertyczni przyszli nauczyciele odczuwają większy poziom niepokoju od swoich ekstrawertycznych kolegów [Pigge, Marso 1994, s. 2-7]. Ponadto wykazano istnienie związku pomiędzy cechami osobowości Wielkiej Piątki a stylem nauczania nauczycieli [Li-fang 2007, s. 669-679].

Na podstawie tego krótkiego przeglądu wyników badań można zauważyć, że pewne cechy osobowości (ekstrawersja, stabilność emocjonalna, otwartość na doświadczenia) mogą mieć pozytywny wpływ na wykonywanie zawodu nauczyciela, z kolei inne cechy osobowości (neurotyzm, introwersja, zamkniętość poznawcza) mogą wywierać negatywny wpływ na pełnienie tej roli zawodowej. Z wyników metaanalizy przeprowadzonej na podstawie 194 badań empirycznych wynika, że sumienność jest negatywnie związana ze wszystkimi zachowaniami mającymi negatywny wpływ na zdrowie (palenie tytoniu, niezdrowa dieta, nadużywanie alkoholu, przemoc, ryzykowne zachowania seksualne etc.), a także pozytywnie skorelowana z zachowaniami prozdrowotnymi. W związku z tym sumienność może być traktowana jako jeden z predyktorów dobrego stanu zdro- 
wia i w związku z tym dobrego funkcjonowania [Bogg, Brent 2004, s. 887; Friedman i in. 1995, s. 696]. Sumienność sprzyja również większej odporności na stres, gdyż osoby sumienne mają skłonność do wybierania bardziej efektywnych strategii radzenia sobie ze stresem [Bartley, Roesch 2011, s. 79], a także większej skłonności do rozwoju zawodowego [Simmering i in. 2003, s. 954.], co jest kluczowe $\mathrm{w}$ zawodzie nauczyciela. $\mathrm{Z}$ kolei ugodowość jest kluczową cechą w kontaktach społecznych. Sprzyja ona budowaniu pozytywnych relacji międzyludzkich. W przypadku konfliktów interpersonalnych ugodowość wiąże się z konstruktywnym rozwiązywaniem konfliktów i nieeskalowaniem konfliktu [Jensen-Campbell, Graziano 2001, s. 323]. Ugodowość jest również skorelowana pozytywnie z motywacją prospołeczną [Graziano i in. 2007, s. 583].

\section{Cyniczna wrogość}

Cechą osobowości będącą w pewnym stopniu zaprzeczeniem ugodowości, chociaż nie jej dokładną odwrotnością, jest cyniczna wrogość. Cecha ta wiąże się dosyć wyraźnie z konfliktowością, ale nie jest tym samym konstruktem. Cyniczna wrogość (ang. cynical hostility) jest rozumiana jako cecha osobowości charakteryzującą się nieufnością, nieżyczliwością i negatywnym nastawieniem do innych osób, sytuowaniem samego siebie w opozycji do innych, a także pragnieniem czynienia im szkód lub oglądania wyrządzonych im szkód [Smith i in. 2004, s. 1217-1270; Sawicki i in. 2015, s. 54]. Cyniczna wrogość składa się z trzech następujących części składowych: 1) cynizmu - rozumianego jako przekonanie o tym, że ludzie w życiu kierują się przede wszystkim własnymi interesami, 2) podejrzliwości - rozumianej jako przeświadczenia o tym, że to inni ludzie są zazwyczaj źródłem niesprawiedliwości, 3) wrogiego stylu atrybucyjnego - rozumianego jako tendencja do przypisywania innym ludziom wrogich intencji oraz interpretowania ich zachowań z tejże perspektywy [Sawicki i in. 2015a, s. 54].

Cyniczna wrogość jest cechą, która może znacznie utrudnić lub wręcz uniemożliwić efektywne pełnienie roli nauczyciela. $Z$ wyników badań nad cyniczną wrogością wyłania się obraz osoby cynicznie wrogiej jako osoby, która cierpi w samotności, nienawidzi świata, jest napięta i nie potrafi tego napięcia zredukować, a także nie wykazuje chęci współpracy [Sawicki i in. 2015b, s. 103-116]. Ludzie cynicznie wrodzy częściej wykazują silniejsze reakcje na sytuację zagrożenia [Smith i in. 2004, s. 1217-1270]. Ciągłe nastawienie na obronę nie sprzyja rozwojowi i obciąża układ nerwowy, a w dalszej perspektywie może prowadzić do chorób sercowo-naczyniowych [Smith, Pope 1990, s. 77]. Brak zaufania do ludzi wiąże się z mniejszym wsparciem społecznym i większą doświadczaną samotnością, co niesie ze sobą szereg negatywnych konsekwencji [Cohen, Wills 1985, s. 310-357]. 
W pracy zawodowej nauczyciela brak zaufania do ludzi może uniemożliwić budowanie relacji z uczniami i pełnienie roli wychowawcy.

Wyniki wstępnych badań nad cyniczną wrogością w kontekście edukacyjnym wykazały, że jest to cecha o jednoznacznie negatywnym zabarwieniu, wiąże się ona z wyraźnie gorszym funkcjonowaniem psychospołecznym, w tym z rzadszym szukaniem wsparcia (emocjonalnego i instrumentalnego) u innych osób oraz częstszym stosowaniem nieefektywnych strategii radzenia sobie ze stresem (takich jak wycofanie zaangażowania) [Sendal i in. 2016a, s. 83-91]. Osoby cynicznie wrogie częściej też interpretowały sytuację trudną (kolokwium) jako zagrożenie lub stratę niż jako wyzwanie lub zysk [Sęktas i in. 2016, s. 104-112]. Wykazano również związek cynicznej wrogości z lękiem i depresyjnością [Sendal i in. 2016b, s. 91-98].

\section{Hipotezy}

Wyniki badań wskazują, że studenci pedagogiki nie wybierają specjalizacji do końca zgodnej z ich predyspozycjami. Blisko 50\% nowych nauczycieli w Stanach Zjednoczonych odchodzi z zawodu w ciągu pierwszych 5 lat od ukończenia studiów [Thornton i in. 2005, s. 489]. Thornton, Peltier i Hill sugerują, że powodzenie i trwałość wykonywania tego zawodu zależne jest od zmiennych osobowościowych.

Zawód nauczyciela jest silnie obciążający, a zwłaszcza zawód nauczyciela dzieci niepełnosprawnych [Plichta 2015, s. 54]. Na podstawie wyników międzynarodowych badań wiadomo, że pedagodzy specjalni częściej z zawodu odchodzą niż pozostali pedagodzy, co może świadczyć o większym obciążeniu psychicznym nauczycieli pracujących z dziećmi i młodzieżą niepełnosprawną [Plichta, s. 54]. Wśród czynników odpowiedzialnych za to, że praca zawodowa pedagogów specjalnych jest szczególnie trudna, wymienia się między innymi konieczność wspierania nie tylko uczniów, ale i ich rodziców, pracę z uczniami ze sprzężonymi niepełnosprawnościami, pracę z osobami o ograniczonej możliwości poprawy ich stanu, czy brak materiałów przydatnych do pracy [Plichta 2015, s. 54].

Takie cechy osobowości, jak ekstrawersja, stabilność emocjonalna, otwartość na doświadczenia, sumienność czy ugodowość, mogą być postrzegane jako zasoby nauczyciela, które chronią go przed negatywnymi konsekwencjami związanymi ze stresem w pracy. Z drugiej strony cyniczna wrogość, neurotyzm, konfliktowość, niesumienność i zamkniętość poznawcza mogą być obciążeniem w dłuższej perspektywie czasu dla osób wykonujących zawód pedagoga specjalnego. Zakładając, że osoby wybierające zawód pedagoga specjalnego robią to w sposób świadomy, opierając się na znajomości własnych predyspozycji, wyniki badania osobowości powinny wykazać istnienie istotnych różnic pomiędzy grupą studen- 
tów pedagogiki i grupą studentów pedagogiki specjalnej. W związku z tym postawiono 6 następujących hipotez badawczych:

H1: Studenci pedagogiki specjalnej są bardziej ekstrawertyczni od studentów pedagogiki.

H2: Studenci pedagogiki specjalnej są bardziej ugodowi niż studenci pedagogiki.

H3: Studenci pedagogiki specjalnej są bardziej sumienni niż studenci pedagogiki.

H4: Studenci pedagogiki specjalnej są bardziej stabilni emocjonalnie niż studenci pedagogiki.

H5: Studenci pedagogiki specjalnej są bardziej otwarci na doświadczenia niż studenci pedagogiki.

H6: Studenci pedagogiki specjalnej są w mniejszym stopniu cynicznie wrodzy niż studenci pedagogiki.

\section{Metody}

Uczestnicy badania. Łącznie w badaniu wzięło udział 355 studentów, w tym 332 kobiety (93,0\% ogółu badanych) i 17 mężczyzn (4,8\%). 8 osób nie zaznaczyło w kwestionariuszu jaką ma płeć $(2,2 \%)$. Średnia wieku respondentów wyniosła 22,17 lat $(S D=4,63)$. Wszyscy studenci studiowali na Wydziale Nauk Społecznych Uniwersytetu Gdańskiego. Studenci pedagogiki stanowili większość uczestników badania (184 osób, 52,4\% ogółu badanych). Studentów pedagogiki specjalnej było $171(47,6 \%)$. Studenci pochodzili z różnych lat studiów i trybów studiów.

Pomiar. Badanymi zmiennymi były cechy osobowości Wielkiej Piątki (ekstrawersja, ugodowość, sumienność, stabilność emocjonalna oraz otwartość na doświadczenia) i cyniczna wrogość. Cechy Wielkiej Piątki były mierzone za pomocą polskiej wersji kwestionariusza Ten Item Personality Inventory (TIPI). Jest to najpopularniejsza metoda pomiaru cech Wielkiej Piątki [Gosling i in. 2003, s. 504-528]. Natomiast cyniczna wrogość była mierzona za pomocą polskiej wersji kwestionariusza Cook-Medley Hostility Inventory - Brief (CMHI Brief) [Cook, Medley, 1954, s. 414-418].

Z poprzednich badań wynika, że kwestionariusz TIPI w polskiej wersji językowej jest narzędziem trafnym i rzetelnym [Atroszko i inni 2015, 2016a, 2016b; P. Atroszko 2015], tak samo jak CMHI Brief [Mokosińska i in. 2016; Sęktas i in. 2016].

Rzetelność zastosowanych narzędzi należy uznać za wystarczającą. W ramach przeprowadzonego badania współczynnik alfa Cronbacha dla skali cynicznej wrogości Cook-Medley Hostility Inventory - Brief wyniósł 0,72. Rzetelność kwestionariusza Ten Item Personality Inventory mierzono za pomocą metody połówkowej współczynnika Spearmana-Browna osobno dla każdego wymiaru. 
Procedura. Dane były zbierane metodą doboru oportunistycznego. Studenci zostali zaproszeni do wzięcia udziału w anonimowym badaniu kwestionariuszowym w czasie zajęć na uczelni (ćwiczeń i wykładów). Zdecydowana większość osób (więcej niż 90\%) zgodziła się i wypełniła kwestionariusz ankiety. Badanie miało miejsce w grudniu 2016 r. oraz w styczniu 2017 r. Za udział w badaniu nie otrzymywali żadnych materialnych korzyści.

Analizy statystyczne. Zastosowano analizę regresji logistycznej do zbadania związku pomiędzy kierunkiem studiów a wybranymi cechami osobowości wśród studentów pedagogiki i pedagogiki specjalnej. Ponadto policzono średnie arytmetyczne, odchylenie standardowe, procenty, a także współczynniki korelacji liniowej Pearsona dla zmiennych ilościowych oraz współczynniki korelacji punktowo-dwuseryjnej dla związku zmiennych dychotomicznych ze zmiennymi ilościowymi. Zastosowano testy dwustronne i przyjęto poziom istotności $\alpha=0,05$. Wszystkie obliczenia statystyczne zostały przeprowadzone w programie IBM SPSS Statistics 24.0.

\section{Wyniki}

\section{Statystyki opisowe}

Ekstrawersja korelowała pozytywnie ze stabilnością emocjonalną oraz otwartością na doświadczenia, a więc im bardziej osoba była ekstrawertyczna, tym statystycznie była też bardziej zrównoważona oraz otwarta na doświadczenia. Ugodowość była związana dodatnio z sumiennością oraz stabilnością emocjonalną, przez co należy rozumieć, że im bardziej badana osoba była ugodowa, tym bardziej też sumienna i zrównoważona. Sumienność była współzależna pozytywnie od stabilności emocjonalnej, czyli im bardziej studentka lub student był/a sumienny, tym bardziej statystycznie był też stabilny emocjonalnie.

Płeć była skorelowana negatywnie z ugodowością $(0=$ kobieta, $1=$ mężczyzna), co oznacza, że w grupie badanych osób kobiety były bardziej ugodowe od mężczyzn. Wiek był związany ujemnie z cyniczną wrogością, a więc im starsza była studentka lub student, tym statystycznie była to osoba w mniejszym stopniu cynicznie wroga. Ugodowość była współzależna odwrotnie z cyniczną wrogością, czyli im bardziej dana osoba była ugodowa, tym mniej była ona cynicznie wroga. Stabilność emocjonalna korelowała negatywnie z cyniczną wrogością, co oznacza, że im bardziej zrównoważona była dana osoba, tym mniej była ona cynicznie wroga (tab. 1). 
Tabela 1. Współczynniki korelacji liniowej Pearsona wybranych cech osobowości studentów pedagogiki i pedagogiki specjalnej

\begin{tabular}{|l|r|r|r|r|r|r|r|r|}
\hline \multicolumn{1}{|c|}{ Zmienna } & Wiek & $\begin{array}{c}\text { Kieru- } \\
\text { nek } \\
\text { studiów }\end{array}$ & $\begin{array}{c}\text { Ekstra- } \\
\text { wersja }\end{array}$ & $\begin{array}{c}\text { Ugo- } \\
\text { dowość }\end{array}$ & $\begin{array}{c}\text { Sumien- } \\
\text { ność }\end{array}$ & $\begin{array}{c}\text { Stabil- } \\
\text { ność } \\
\text { emocjo- } \\
\text { nalna }\end{array}$ & $\begin{array}{c}\text { Otwar- } \\
\text { tość na } \\
\text { doświad } \\
\text { czenia }\end{array}$ & $\begin{array}{c}\text { Cynicz- } \\
\text { na wro- } \\
\text { gość }\end{array}$ \\
\hline Płeća & 0,03 & 0,02 & $-0,06$ & $-0,18^{* *}$ & $-0,09$ & 0,03 & $-0,04$ & 0,07 \\
\hline Wiek & & 0,10 & $-0,010$ & 0,11 & 0,01 & 0,07 & $-0,06$ & $-0,13^{*}$ \\
\hline Kierunek studiówb & & & $-0,013$ & 0,06 & 0,04 & $-0,003$ & $-0,04$ & $-0,05$ \\
\hline Ekstrawersja & & & & $-0,01$ & 0,08 & $0,16^{* *}$ & $0,25^{* *}$ & $-0,03$ \\
\hline Ugodowość & & & & & $0,29^{* *}$ & $0,43^{* *}$ & 0,06 & $-0,27^{* *}$ \\
\hline Sumiennóśc & & & & & & $0,31^{* *}$ & 0,10 & 0,003 \\
\hline Stabilność emoc. & & & & & & & $-0,02$ & $-0,14^{* *}$ \\
\hline $\begin{array}{l}\text { Otwartość } \\
\text { na doświadczenia }\end{array}$ & & & & & & & & $-0,004$ \\
\hline
\end{tabular}

a 0 = kobieta, 1 = mężczyzna; współczynniki korelacji punktowo-duseryjnej

b 0 = pedagogika, 1 = pedagogika specjalna; współczynniki korelacji punktowo-duseryjnej

$N=329 ;{ }^{*} \mathrm{p}<.05 ;{ }^{* *} \mathrm{p}<.01$.

Źródło: Opracowanie własne.

Badanie związku pomiędzy kierunkiem studiów i wybranymi cechami osobowości za pomocą analizy regresji logistycznej

Przeprowadzono analizę regresji logistycznej, w której kierunek studiów (pedagogika vs. pedagogika specjalna) był zmienną zależną w modelu, zaś płeć, wiek, cechy osobowości Wielkiej Piątki (ekstrawersja, ugodowość, sumienność, stabilność emocjonalna i otwartość na doświadczenia) i cyniczna wrogość były predyktorami. Z przeprowadzonej analizy regresji logistycznej wynika, że żaden z przyjętych predyktorów w modelu nie przewidywał w sposób istotny statystycznie zmiennej zależnej (tab. 2). 
Tabela 2. Wyniki analizy regresji logistycznej, w której kierunek studiów (pedagogika vs. pedagogika specjalna) jest funkcją płci, wieku, cech osobowości Wielkiej Piątki (ekstrawersja, ugodowość, sumienność, stabilność emocjonalna, otwartość na doświadczenia) i cynicznej wrogości

\begin{tabular}{|c|c|c|c|c|c|c|}
\hline \multirow{2}{*}{ Variables } & \multirow{2}{*}{$B$} & \multirow{2}{*}{$\begin{array}{l}\text { Wald Chi- } \\
\text { kwadrat }\end{array}$} & \multirow{2}{*}{$p$} & \multirow{2}{*}{$\begin{array}{l}\text { Iloraz } \\
\text { szans }\end{array}$} & \multicolumn{2}{|c|}{$\begin{array}{l}95 \% \text { przedział ufności } \\
\text { dla ilorazu szans }\end{array}$} \\
\hline & & & & & $\begin{array}{l}\text { dolna } \\
\text { granica }\end{array}$ & $\begin{array}{l}\text { górna } \\
\text { granica }\end{array}$ \\
\hline Płeća & 0,432 & 0,674 & 0,412 & 1,541 & 0,549 & 4,321 \\
\hline Wiek & 0,041 & 1,782 & 0,182 & 1,042 & 0,981 & 1,108 \\
\hline Ekstrawersja & $-0,017$ & 0,130 & 0,718 & 0,983 & 0,895 & 1,079 \\
\hline Ugodowość & 0,076 & 1,246 & 0,264 & 1,078 & 0,945 & 1,231 \\
\hline Sumienność & 0,046 & 0,771 & 0,380 & 1,047 & 0,945 & 1,159 \\
\hline Stabilność emocjonalna & $-0,039$ & 0,569 & 0,451 & 0,962 & 0,870 & 1,064 \\
\hline $\begin{array}{l}\text { Otwartość } \\
\text { na doświadczenia }\end{array}$ & $-0,033$ & 0,300 & 0,584 & 0,967 & 0,858 & 1,090 \\
\hline Cyniczna wrogość & $-0,021$ & 0,545 & 0,460 & 0,979 & 0,926 & 1,036 \\
\hline Constant & $-1,074$ & 0,609 & 0,435 & 0,341 & & \\
\hline
\end{tabular}

a $0=$ kobieta, $1=$ mężczyzna

$N=329 ;{ }^{*} \mathrm{p}<.05 ;{ }^{* *} \mathrm{p}<.01$

Źródło: Opracowanie własne.

\section{Dyskusja}

Żadna z sześciu przyjętych hipotez nie została potwierdzona. Nie wykazano, aby studenci pedagogiki specjalnej byli bardziej ugodowi, otwarci na doświadczenia, stabilni emocjonalnie, sumienni czy ekstrawertyczni niż studenci pedagogiki. Nie było też różnicy w poziomie cynicznej wrogości pomiędzy obiema grupami studentów.

W poprzednim artykule prezentującym wyniki badania na tej samej próbie studentów również nie wykazano statystycznie istotnej różnicy pomiędzy studentami pedagogiki i pedagogiki specjalnej pod względem samoskuteczności i bezradności [Atroszko i in. 2017b, s. 124-127]. Wyniki tego oraz poprzedniego badania są zaskakujące, ponieważ wskazują one na to, że pomiędzy obiema grupami studentów nie ma żadnych istotnych różnic w zakresie cech osobowości. Zawód pedagoga specjalnego jest specyficzny i bardzo wymagający. Z pewnością nie wystarczą same kwalifikacje formalne, aby należycie go wykonywać. Potrzebne są też do tego odpowiednie cechy osobowości i predyspozycje, takie jak: cierpli- 
wość, empatia oraz życzliwość do ludzi etc. W związku z tym można by przypuszczać, że osoby wybierające ten zawód będą pod względem cech osobowości różnić się od innych osób. Jednak na podstawie wyników przeprowadzonych badań nie można wysnuć takiego wniosku.

Należy wspomnieć, że obie grupy studentów różniły się w sposób istotny statystycznie pod względem wyznawanych wartości. Studenci pedagogiki specjalnej w mniejszym stopniu cenili wartości hedonistyczne od studentów pedagogiki [Atroszko i in. 2017a, s. 111-114]. Jednak wyznawanych wartości nie można uznać za wystarczające predyspozycje dla skutecznego pełnienia roli pedagoga specjalnego.

\section{Wnioski}

W wyniku przeprowadzonego badania nie wykazano istotnej statystycznie różnicy pomiędzy studentami pedagogiki i pedagogiki specjalnej pod względem cech osobowości Wielkiej Piątki i cynicznej wrogości. Uzyskane dane sugerują, że decyzja o podjęciu przez studentów studiów w zakresie pedagogiki specjalnej dla wielu osób może wiązać się z brakiem świadomości na temat wymagań i predyspozycji związanych z zawodem pedagoga specjalnego. Przedstawione wyniki badania oraz cały niniejszy artykuł można potraktować jako głos w dyskusji na temat kształcenia przyszłych nauczycieli i pedagogów, głos dotyczący indywidualnych predyspozycji osobowościowych do wykonywania przyszłego zawodu przez studentów pedagogiki specjalnej.

\section{Bibliografia}

Atroszko P.A. (2015), Struktura uzależnienia studentów od uczenia się: wybrane czynniki ryzyka, zwiazek ze stresem i strategiami radzenia sobie oraz funkcjonowaniem psychospotecznym, praca doktorska napisana pod kierunkiem M. Cioska i obroniona w 2015 r. na Uniwersytecie Gdańskim, na Wydziale Nauk Społecznych, w Instytucie Psychologii.

Atroszko P.A., Andreassen C.S., Griffiths M.D., Pallesen S. (2015), Study Addiction - A New Area of Psychological Study: Conceptualization, Assessment, and Preliminary Empirical Findings, "Journal of Behavioral Addictions", vol. 4(2), s. 75-84.

Atroszko P.A., Andreassen C.S., Griffiths M.D., Pallesen S. (2016), Study Addiction: A CrossCultural Longitudinal Study Examining Temporal Stability and Predictors of Its Changes, "Journal of Behavioral Addictions", vol. 5(2), s. 357-362.

Atroszko P.A., Andreassen C.S., Griffiths M.D., Pallesen S. (2016), The relationship between study addiction and work addiction: A cross-cultural longitudinal study, "Journal of Behavioral Addictions", vol. 5(4), s. 708-714. 
Atroszko B., Sawicki A., Mąkinia A. (2017) The most important values for pedagogy and special education students [w:] CER Comparative European Research 2017, M. McGreevy, R. Rita (red.), Sciemcee, London, s. 111-114.

Atroszko B., Swarra A., Sendal L. (2017), A comparison of general education students and special education students in terms of self-efficacy and hopelessness [w:] CER Comparative European Research 2017, M. McGreevy, R. Rita (red.), Sciemcee, London, s. 124-127.

Bartley C.E., Roesch S.C. (2011), Coping with daily stress: The role of conscientiousness, „Personality and Individual Differences", vol. 50, issue 1, s. 79-83.

Bogg T., Brent W. (2004), Conscientiousness and Health-Related Behaviors: A Meta-Analysis of the Leading Behavioral Contributors to Mortality, „Psychological Bulletin”, vol. 130(6), s. 887-919.

Brownell M.T., Ross D.D., Colón E.P., McCallum C.L. (2005), Critical Features of Special Education Teacher Preparation A Comparison With General Teacher Education, "The Journal of Special Education", vol. 38, issue 4, s. 242-252.

Cohen S., Wills T. (1985), Stress, social support, and the buffering hypothesis, „Psychological Bulletin", vol. 98(2), s. 310-357.

Cook W.W., Medley D.M. (1954), Proposed hostility and pharisaic-virtue scales for the MMPI, "Journal of Applied Psychology", vol. 38(6), s. 414-418.

Day Ch. (2004), Rozwój zawodowy nauczyciela. Uczenie się przez całe życie, Gdańskie Wydawnictwo Psychologiczne, Gdańsk.

Fariselli L., Ghini M., Freedman J. (2006), Age and emotional intelligence, raport na temat związku wieku oraz inteligencji emocjonalnej dostępny na stronie internetowej https://www.6seconds. org/sei/media/WP_EQ_and_Age. pdf [dostęp: 21.10.2017].

Fontana D., Abouserie R. (1993), Stress levels, gender and personality factors in teachers, „British Journal of Educational Psychology", vol. 63, issue 2, s. 261-270.

Friedman H.S., Tucker J.S., Schwartz J.E., Martin L.R. i in., Childhood conscientiousness and longevity: Health behaviors and cause of death, "Journal of Personality and Social Psychology", vol. 68(4), s. 696-703.

Gosling S.D., Rentfrow P.J., Swann W.B. Jr (2003), A very brief measure of the Big-Five personality domains, "Journal of Research in Personality", vol. 37, s. 504-528.

Graziano W.G., Habashi M.M., Sheese B.E., Tobin R.M. (2007), Agreeableness, empathy, and helping: A person x situation perspective, "Journal of Personality and Social Psychology", vol. 93(4), s. 583-599.

Hall C.S., Lindzey G., Campbell J.B. (2004), Teorie osobowości, wydanie nowe, Wydawnictwo Naukowe PWN, Warszawa.

Jensen-Campbell L.A., Graziano W.G. (2001), Agreeableness as a Moderator of Interpersonal Conflict, " "Journal of Personality", vol. 69, issue 2, s. 323-362.

Kawka Z. (1998), Między misją a frustracją. Społeczna rola nauczyciela, Wydawnictwo Uniwersytetu Łódzkiego, Łódź.

Kokkinos C.M. (2007), Job stressors, personality and burnout in primary school teachers, „British Journal of Educational Psychology", vol. 77, issue 1, s. 229-243.

Kordziński J. (2013), Nauczyciel, trener, coach, Wolters Kluwer Polska, Warszawa.

Krause A. (2009), Teoretyczne i empiryczne problemy pedagogiki specjalnej. Zarys obszarów badawczych, "Niepełnosprawność. Półrocznik Naukowy”, nr 1, s. 9-24. 
Lee I.R., Kemple K. (2014), Preservice Teachers' Personality Traits and Engagement in Creative Activities as Predictors of Their Support for Children's Creativity, "Creativity Research Journal", vol. 26, issue 1, s. 82-94.

Li-fang Zhang (2007), Do personality traits make a difference in teaching styles among Chinese high school teachers?, „Personality and Individual Differences”, vol. 43, issue 4, s. 669-679.

Mokosińska M., Sawicki A., Atroszko P.A. (2016). Relationship between cynical hostility and socioeconomic status from educational perspective. Preliminary research [w:] Badania i rozwój młodych naukowców w Polsce. Nauki humanistyczne i społeczne, J. Leśny, J. Nyćkowiak (red.), Młodzi Naukowcy, Poznań, s. 41-48.

Myers D.G. (2003), Psychologia, Zysk i S-ka Wydawnictwo, Poznań.

Ngidi D.P., Sibaya P.T. (2002), Black Teachers' Personality Dimensions and Work-Related Stress Factors, „South African Journal of Psychology”, vol. 32, issue 3, s. 7-15.

Parys K., Olszewski S. (2009), Ewolucja pogląó́w na temat kształcenia pedagogów specjalnych w Polsce, „Niepełnosprawność. Półrocznik Naukowy”, nr 1, s. 103-112.

Plichta P. (2015), Wypalenie zawodowe i poczucie sensu życia pedagogów specjalnych, Oficyna Wydawnicza ATUT - Wrocławskie Wydawnictwo Oświatowe, Wrocław.

Raport Biura Karier Uniwersytetu Pedagogicznego w Krakowie, https://bks.up.krakow.pl/ htmlarea/uploaded/pedagogika_specjalna_2013.pdf [dostęp: 21.10.2017].

Rudek I. (2002), Poznawanie ucznia i diagnozowanie wychowawcze jako konieczne umiejętności nauczyciela [w:] Kompetencje nauczyciela wychowawcy, K. Ferenz, E. Kozioł (red.), Redakcja Wydawnictw Humanistyczno-Społecznych Uniwersytetu Zielonogórskiego, Zielona Góra, s. 125-134.

Sawicki A., Atroszko B., Atroszko P. (2015a), Uwarunkowania i potencjalne konsekwencje cynicznej wrogości w perspektywie edukacyjnej [w:] Psychospołeczne aspekty zdrowia, A. Nawrocka, F. Makurat, R. Breska (red.), Wydawnictwo Athenae Gedanenses, Gdańsk, s. 51-68.

Sawicki A., Mokosińska M., Atroszko B., Malinowska S. (2015b), Cyniczna wrogość wśród studentów - podsumowanie wstępnych badań [w:] Psychospołeczne aspekty zdrowia, nauk. A. Nawrocka, F. Makurat, R. Breska (red.), Wydawnictwo Athenae Gedanenses, Gdańsk 2015, s. 103-116.

Sendal L., Krzyżaniak P., Raczyńska A., Atroszko P. (2016a), The mediating effect of coping strategies on cynical hostility and perceived stress - preliminary findings [w:] Badania i Rozwój Młodych Naukowców w Polsce. Nauki humanistyczne i społeczne, J. Leśny, J. Nyćkowiak (red.), Młodzi Naukowcy, Poznań, s. 83-91.

Sendal L., Sawicki A., Bagińska P., Atroszko P. (2016b), Relationship of cynical hostility with anxiety and depressiveness among university students in Poland [w:] Badania i Rozwój Młodych Naukowców w Polsce. Nauki humanistyczne i społeczne, J. Leśny, J. Nyćkowiak (red.), Młodzi Naukowcy, Poznań 2016, s. 91-98.

Sęktas M., Krzyżaniak P., Raczyńska A., Atroszko P.A. (2016), Relationship between cynical hostility and primary emotional appraisal of a stressful situation of academic test [w:] Badania i Rozwój Młodych Naukowców w Polsce. Nauki humanistyczne i społeczne, J. Leśny, J. Nyćkowiak (red.), Młodzi Naukowcy, Poznań, s. 104-112.

Simmering M.J. i in. (2003), Conscientiousness, Autonomy Fit, and Development: A Longitudinal Study, ,Journal of Applied Psychology”, vol. 88, no. 5, s. 954-963. 
Smith T.W., Glazer K., Ruiz J., Gallo L. (2004), Hostility, Anger, Aggressiveness, and Coronary Heart Disease: An Interpersonal Perspective on Personality, Emotion, and Health, "Journal of Personality", vol. 72(6), s. 1217-1270.

Smith T.W., Pope M.K. (1990), Cynical hostility as a health risk: Current status and future directions, "Journal of Social Behavior and Personality", vol. 5, s. 77-88.

Strzyżewska M. (2002), Kompetencje nauczycieli uczacych dzieci ze specjalnymi potrzebami edukacyjnymi [w:] Kompetencje nauczyciela wychowawcy, K. Ferenz, E. Kozioł (red.), Redakcja Wydawnictw Humanistyczno-Społecznych Uniwersytetu Zielonogórskiego, Zielona Góra, s. 53-63.

Thornton B., Peltier G., Hill G. (2005), Do Future Teachers Choose Wisely? A Study of Pre-Service Teachers' Personality Preference Profiles, "College Student Journal”, vol. 39, issue 3, s. 489-496.

Wosik-Kawali D., Zubrzycka-Maciąg T. (2011), Wstęp [w:] Kompetencje diagnostyczne i terapeutyczne nauczyciela, D. Wosik-Kawali, T. Zubrzycka-Maciąg (red.), Oficyna Wydawnicza „Impuls”, Kraków, s. 7-9.

Van Rooya D.L., Alonsob A., Viswesvaranc Ch. (2005), Group differences in emotional intelligence scores: theoretical and practical implications, „Personality and Individual Differences”, vol. 38, issue 3, s. 689-700. 